Krogh, T. E. \& Davis, G. L. 1973: The effect of regional metamorphism on U-Pb systems in zircon and a comparison with $\mathrm{Rb}-\mathrm{Sr}$ systems in the same whole rock and its constituent minerals. Carnegie Inst. Wash. Yb. 72, 601-610.

Larsen, O. 1966: K/Ar age determinations from western Greenland. Rapp. Grønlands geol. Unders. 11, $57-67$.

Larsen, O. 1971: Reconnaissance K/Ar dating of samples from West Greenland between Søndre Strømfjord and Frederikshåb Isblink. Rapp. Grønlands geol. Unders. 35, 44-48.

Larsen, O. \& Møller, J. 1968: K/Ar determinations from western Greenland I. Reconnaissance programme. Rapp. Grønlands geol. Unders. 15, 82-86.

Moorbath, S. \& Pankhurst, R. J. 1976: Further rubidium-strontium age and isotope evidence for the nature of the late Archaean plutonic event in West Greenland. Nature, Lond. 262, 124-126.

Pidgeon, R. T. \& Hopgood, A. M. 1975: Geochronology of Archaean gneisses and tonalites from north of the Frederikshåbs isblink, S. W. Greenland. Geochim. Cosmochim. Acta 39, 1333-1346.

Pidgeon, R. T., Aftalion, M. \& Kalsbeek, F. 1976: The age of the Ilivertalik granite in the Fiskenæsset area. Rapp. Grønlands geol. Unders. 73, 31-33.

C.R.L.F.,

Department of Geology,

Oxford Polytechnic,

Headington,

Oxford OX3 OBP,

U.K.
A.D.M.B.,

Department of Earth Sciences,

University of Leeds,

Leeds LS2 9JT,

U.K.

D.J.H.,

Department of Geology, Portsmouth Polytechnic,

Burnaby Road,

Portsmouth PO1 3QL,

U.K.

\title{
Potassium-argon ages from Phanerozoic basic dykes in South-East Greenland
}

\author{
J. G. Mitchell
}

\section{Introduction}

Nine basaltic dykes were sampled by coring during geological reconnaissance of the south-east coast of Greenland (Bridgwater et al., 1977) between Angmagssalik $\left(65^{\circ} 40^{\prime}\right)$ and Nordfjord (fig. 49). The samples were initially collected for palaeomagnetic investigations (Beckmann, 1977). In the field it was assumed that all the fresh basic dykes in the region were Tertiary in age and represented a southern continuation of the coastal dyke swarm described by Wager \& Deer (1938). The timing of dyke injection is very important as a possible indication of the initial break-up of the original North Atlantic mass. Furthermore, it was assumed that the major coast-parallel dyke swarm (for example site $26 \& 28$, see fig. 49) was the continuation of the more intense Tertiary dyke swarm reported by Wager \& Deer (1938) further north, while the more sporadic dykes with other trends were presumed also to belong to the same general period of injection. The preliminary palaeomagnetic studies by Beckmann (1977) showed no consistent differences between dykes grouped according to their trends. 


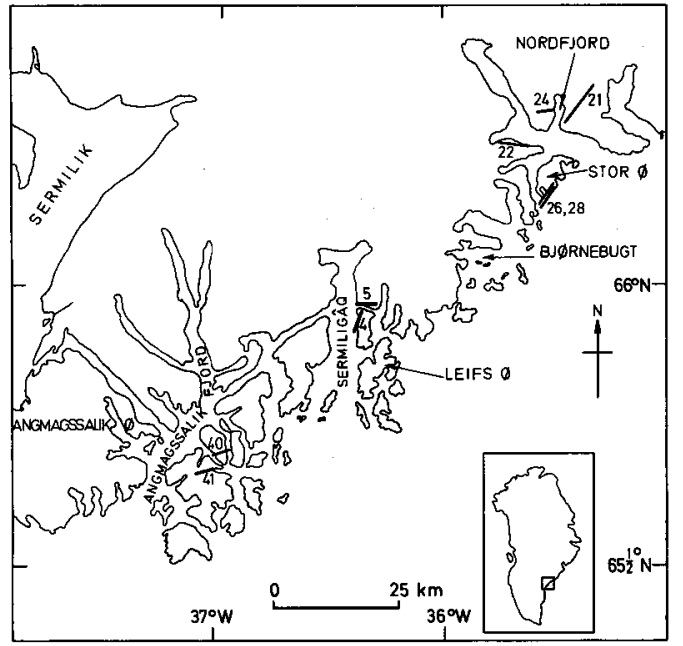

Fig. 49. Map of the sampling area in South-East Greenland showing localities of basic dykes used in the K-Ar analysis, and their regional trends.

\section{$K$-Ar age determinations}

Whole-rock and mineral concentrate ages were determined using the methods described by Mitchell (1972) and the results of the analyses are presented in Table 11. At least four stages of dyke emplacement are represented in this reconnaissance collection and it is clear that the unmetamorphosed dykes from this region can no longer be assumed to be Tertiary.

The whole-rock dyke ages from the southern section of the field area (group E, Table 11) are all Tertiary ranging from $45.8 \pm 1.5 \mathrm{~m} . \mathrm{y}$. to $61.9 \pm 1.6 \mathrm{~m} . \mathrm{y}$. The freshest sample of this group (site 4) - tholeiitic basalt, 40 per cent labradorite $\left(\mathrm{An}_{55}\right), 40$ per cent augite, 10 per cent olivine - was selected for mineral analysis and plagioclase and pyroxene concentrates were prepared using heavy-liquids. The concordant mineral ages obtained, $62.0 \mathrm{~m} . \mathrm{y}$., demonstrate that argon loss is not significant in samples from this site, nor, indeed is the existence of excess (initial) argon likely. These four dykes are therefore thought to be of Tertiary age having cooled to below their argon blocking temperature some 62 m.y. ago, minor argon loss having subsequently occurred in two of the samples. This age is significantly older than the K-Ar ages reported from Tertiary volcanic rocks from Scoresby Sund by Hailwood et al. (1973) who reported an age of around 49 m.y. for the tholeiitic lavas and a dyke in that area. However, Beckinsale et al. (1970) have obtained K-Ar ages from Tertiary lavas south of Scoresby Sund which they interpret as demonstrating extrusion to have occurred at a time in excess of $57 \mathrm{~m} . y$. ago. Thus the Tertiary ages reported from Angmagssalik would accord with the latter findings, as well as with the better documented ages of similar tholeiitic dykes and lavas from the British Tertiary igneous province, summarised by Macintyre (1973), which exhibit a major period of dyke emplacement close to 60 m.y. This dominantly ENE swarm appears to pre-date the major coast parallel dykes north of $66^{\circ} \mathrm{N}$.

The northern part of the sampling area is characterised by a wide diversity of $\mathrm{K}-\mathrm{Ar}$ whole-rock dyke ages ranging from $78.5 \mathrm{~m}$.y. to $548 \mathrm{~m}$.y. In view of the small scatter in the palaeomagnetic pole positions from all these samples (interpreted initially as being of Terti- 
Table 11. K-Ar data for basic dykes between Angmagssalik and Nordfjord, SouthEast Greenland

\begin{tabular}{|c|c|c|c|c|c|c|c|}
\hline Site no. & Sample & $\mathrm{K}_{2} \mathrm{O}$ & $\begin{array}{c}\text { Radiogenic } \\
\mathrm{mm}^{3} \mathrm{gm}^{-1} \mathrm{Ar} \\
10^{-4}\end{array}$ & $\begin{array}{l}\text { Atmospheric } \\
40 \mathrm{Ar}\end{array}$ & $c \underset{\left(\mathrm{m}, y_{.}\right)}{\text {Age }}$ & Strike & Group \\
\hline 22 & $\begin{array}{l}\text { Whole rock } \\
\text { Plagioclase } \\
\text { Pyroxene }\end{array}$ & $\begin{array}{l}0.510 \\
0.797 \\
0.156\end{array}$ & $\begin{array}{r}107.2 \\
169.2 \\
33.5\end{array}$ & $\begin{array}{r}8.8 \\
7.0 \\
16.5\end{array}$ & $\begin{array}{l}548 \pm 6 \\
552 \pm 6 \\
558 \pm 8\end{array}$ & 100 & A \\
\hline 24 & $\begin{array}{l}\text { Whole rock } \\
\text { Plagioclase } \\
\text { Pyrozene }\end{array}$ & $\begin{array}{l}0.562 \\
0.538 \\
0.367\end{array}$ & $\begin{array}{l}31.8 \\
29.6 \\
22.6\end{array}$ & $\begin{array}{l}14.1 \\
47.3 \\
28.7\end{array}$ & $\begin{array}{l}164 \pm 3 \\
159 \pm 3 \\
178 \pm 3\end{array}$ & 085 & $B$ \\
\hline 21 & $\begin{array}{l}\text { Whole rock } \\
\text { Whole rock } \\
\text { Plagioclase } \\
\text { Pyroxene }\end{array}$ & $\begin{array}{l}0.455 \\
0.472 \\
0.832 \\
0.432\end{array}$ & $\begin{array}{l}15.8 \\
16.9 \\
23.1 \\
13.6\end{array}$ & $\begin{array}{l}16.0 \\
17.8 \\
22.0 \\
39.2\end{array}$ & $\begin{array}{r}102 \pm 2 \\
105 \pm 2 \\
82.2 \pm 1.5 \\
92.9 \pm 2.0\end{array}$ & 040 & $c$ \\
\hline 26 & Whole rock & 0.370 & 10.4 & 51.3 & $83.0 \pm 1.8$ & 0.34 & \\
\hline 28 & $\begin{array}{l}\text { Whole rook } \\
\text { Plagioclase } \\
\text { Pyroxene }\end{array}$ & $\begin{array}{l}0.562 \\
0.862 \\
0.471\end{array}$ & $\begin{array}{l}14.9 \\
22.0 \\
12.2\end{array}$ & $\begin{array}{l}19.0 \\
24.8 \\
44.7\end{array}$ & $\begin{array}{l}78.5 \pm 1.5 \\
75.5 \pm 1.8 \\
76.7 \pm 2.2\end{array}$ & 0.34 & $\mathrm{D}$ \\
\hline 40 & Whole rock & 0.364 & 7.58 & 26.6 & $61.9 \pm 1.6$ & 0.71 & \\
\hline 04 & $\begin{array}{l}\text { Whole rock } \\
\text { Plagioclase } \\
\text { Pyroxene }\end{array}$ & $\begin{array}{l}0.435 \\
0.671 \\
0.298\end{array}$ & $\begin{array}{c}8.56 \\
14.0 \\
6.21\end{array}$ & $\begin{array}{l}25.1 \\
21.0 \\
40.4\end{array}$ & $\begin{array}{l}58.6 \pm 1.5 \\
62.1 \pm 1.5 \\
62.0 \pm 2.0\end{array}$ & 0.20 & $\mathrm{E}$ \\
\hline 05 & Whole rock & 0.479 & 8.82 & 37.1 & $54.9 \pm 1.4$ & 0.90 & \\
\hline 41 & Whole rock & 0.791 & 12.1 & 49.9 & $45.8 \pm 1.5$ & 0.80 & \\
\hline $\begin{array}{l}\lambda_{e}=0.5 \\
\lambda_{\beta}=4.7\end{array}$ & $\begin{array}{l}84 \times 10^{-10} \mathrm{yr}^{-} \\
2 \times 10^{-10} \mathrm{y} \mathrm{r}^{-1}\end{array}$ & & $40_{K} / K=1.19$ & $19 \times 10^{-2}$ atom & & $n t$ & \\
\hline \multicolumn{8}{|c|}{$\begin{array}{l}\mathrm{K}_{2} \mathrm{O} \text { analyses mean of } 3 \text { determinations } \\
4 \mathrm{Ar}_{\mathrm{Ar}} \text { analyses mean of } 2 \text { determinations. Atmospher } \\
\text { higher of the two values recorded in these } \\
\text { Error quoted is to estimate based on analytical p }\end{array}$} \\
\hline
\end{tabular}

ary age, Beckmann, 1977) it was decided to investigate the possible existence of excess argon in a selection of them. For this purpose, plagioclase and pyroxene concentrates were prepared and their K-Ar ages are given in Table 11.

Sample from site 22 is taken from a dyke with an unusual trend $\left(100^{\circ}\right)$. It yielded a Cambrian age of $553 \pm 6$ m.y., meaned over the whole-rock and mineral data. Furthermore, the existence of the phenomenon of excess argon, or that of argon loss in this sample, can be discounted in view of the close concordance between the ages obtained. This dyke is a tholeiitic basalt containing 50 per cent labradorite $\left(\mathrm{An}_{60}\right), 40$ per cent augite, 5 per cent olivine and showing only slight alteration. In view of its undeformed appearance, it is concluded that the age obtained is the time at which this dyke was emplaced during the Cambrian. Igneous activity of this age is widespread in western Greenland where phlogopite ages of 570-580 m.y. have been found from the extensive kimberlites and related carbona- 
tites in the Holsteinsborg area (R. M. Macintyre, personal communication; Bridgwater, 1970, 1971). A similar age has been obtained from a lamprophyre dyke at Umanak $500 \mathrm{~km}$ to the north (Larsen \& Møller, 1968). In general, widespread emplacement of alkaline rocks occurred at this time from the St. Lawrence Rift to the Fen Complex in southern Norway. Evidence for the timing of this igneous event in the North Atlantic has been reviewed by Macintyre (1971). The identification of a possible expression of this event in eastern Greenland is, therefore, not unexpected.

Samples from site 24 are in thin section, somewhat more altered than 22 but are still considered suitable for $\mathrm{K}-\mathrm{Ar}$ analysis. They contain 40 per cent andesine $\left(\mathrm{An}_{45}\right)$ and 40 per cent augite with olivine showing extensive alteration to chlorite. The whole-rock age of $164 \pm 2 \mathrm{~m} . \mathrm{y}$. was at first sight potentially anomalous, and it was investigated further using mineral separates of plagioclase and pyroxene. The spread in potassium content obtained in this way was not large (a factor of about 1.5), and thus possible test of the existence of excess argon in a potassium-deficient phase was rendered difficult. However, in view of the small spread in age obtained, $164 \pm 3 \mathrm{~m} . \mathrm{y}$. to $178 \pm 3 \mathrm{~m} . \mathrm{y}$. it is considered highly unlikely that a level of excess argon in the different mineral phases is correlated with their radiogenic argon contents in such a way as to produce the small spread in age. In view of the somewhat altered nature of the sample, it is considered to be at least lower Jurassic age, and possibly somewhat older. Igneous activity in the North Atlantic was also widespread at this time, and in particular, ages of 162 m.y. and 168 m.y. obtained for biotite from lamprophyres in western Greenland (Larsen \& Møller, 1968; Bridgwater, 1700) and an age of 164 m.y. for a coast parallel dyke from Sunnhordland in western Norway (Faerseth et al., 1976) bear comparison. A fuller review of the numerous data which evidence this mid-Jurassic event in the North Atlantic has been given by Halliday (1977).

A geologically somewhat unexpected age was obtained from samples from sites 26 and 28 which have identical strike $\left(034^{\circ}\right)$ and which are geographically within $100 \mathrm{~m}$ of each other. These dykes are emplaced along pronounced coast-parallel fracture zones and are regarded as typical members of the 'Tertiary' swarm. The whole-rock K-Ar ages of $83.0 \pm 1.8 \mathrm{~m} . \mathrm{y}$. and $78.5 \pm 1.5 \mathrm{~m}$.y. are further substantiated by concordant mineral ages for the latter dyke, and the data strongly suggest a period of dyke emplacement in late Cretaceous times, quite distinct from the vulcanism and dyke emplacement which followed some 15-20 m.y. later. The significance of the age is further substantiated by the petrographically fresh appearance of the rocks with a composition of 60 per cent andesine $\left(\mathrm{An}_{40}\right), 30$ per cent augite, with no olivine or alteration products from it.

The significance of the age of samples from site 21 is less certain. Composition is tholeiitic basalt, containing 60 per cent labradorite $\left(\mathrm{An}_{50}\right), 30$ per cent augite, with olivine showing extensive alteration. Whole-rock analyses of two independent cores yielded concordant ages of $102 \pm 2 \mathrm{~m}$.y. and $105 \pm 2 \mathrm{~m}$.y. Normally this concordancy would be taken to imply geological significance of the age, but the discordant mineral ages (plagioclase yielding $82.2 \pm 1.5$ m.y. and pyroxene $92.9 \pm 2.0$ m.y.) and relatively altered appearance of the rock in thin-section, militate against this simple interpretation.The strike of this dyke $\left(040^{\circ}\right)$ is similar to that of the nearby late Cretaceous dykes (group D), but with the limited isotopic data available, it is impossible to argue unambiguously whether this dyke is of this age, and has occluded excess argon at its time of formation, or whether the dyke represents a still earlier phase of dyke emplacement prior to 105 m.y. 


\section{Conclusions}

The scatter in ages presented suggests that there was at least four and possibly more periods of dyke injection in this part of South-East Greenland during Phanerozoic time. Although individual ages may be subject to either argon loss or gain, the coincidence in ages obtained from dykes in the same area and between mineral fractions and whole-rock ages on the same sample strongly supports the contention that the ages reported reflect real events. None of the ages reported agree with the main phase of coast-parallel dyke injection between 55 and 50 m.y. further north suggesting either that this swarm does not follow the coast line as it swings to the south-west and west now but that it either dies out or continues beneath the sea to the east of the area shown in fig. 49. If it is presumed that periods of dyke injection are controlled by major earth movements then a remarkably complex history is recorded in this area reflecting pre-Caledonian instability and Mesozoic to early Tertiary movements possibly linked to graben formation in the continental area now covered by the sea. A regional study of the timing of dyke emplacement on-shore would seem to be of considerable application to the study of off-shore geophysical data and the possible evaluation of the economic potential of the area.

\section{Acknowledgements}

G. E. J. Beckmann (Univ. of Riyadh, Saudi Arabia) is thanked for interesting the writer in the problem and in supplying samples and field observations. Geological interpretations are based on field work by GGU geologists and D. Bridgwater critically revised an earlier version of the text.

\section{References}

Beckinsale, R. D., Brooks, C. K. \& Rex, D. C. 1970: K-Ar ages for the Tertiary of East Greenland. Bull. geol. Soc. Denmark 20, 27-37.

Beckmann, G. E. J. 1977: Palaeomagnetic investigations in South-East Greenland. Rapp. Grønlands geol. Unders. 85, 84-85.

Bridgwater, D. 1970: A compilation of K/Ar age determinations on rocks from Greenland carried out in 1969. Rapp. Gronlands geol. Unders. 28, 47-55.

Bridgwater, D., 1971: Routine K/Ar age determinations on rocks from Greenland carried out for GGU in 1970. Rapp. Grønlands geol. Unders. 35, 52-60.

Bridgwater, D., Davies, F. B., Gill. R.C.O., Gorman, B. E., Henriksen, N. \& Watterson, J. 1977: Field mapping in the Nagssugtoqidian of South-East Greenland. Rapp. Grønlands geol. Unders. 85, 74-83.

Faerseth, R. B., Macintyre, R. M. \& Naterstad, J. 1976: Mesozoic alkaline dykes in the Sunnhordland region, western Norway: ages, geochemistry and regional significance. Lithos 9, 331-345.

Hailwood, E. A., Tarling, D. H., Mitchell, J. G. \& Løvlie, R., 1973: Preliminary observations on the palaeomagnetism and radiometric ages of the Tertiary basalt sequence of Scoresby Sund, East Greenland. Rapp. Grønlands geol. Unders. 58, 43-47.

Halliday, A. N. 1977: Isotopic age studies of mineralisation in western Europe. Unpubl. Ph. D. thesis, Univ. of Newcastle upon Tyne, U. K.

Larsen, O. \& Møller, J. 1968: Potassium-argon age studies in West Greenland. Can. J. Earth Sci. 5, 683-691.

Macintyre, R. M. 1971: Apparent periodicity of carbonatite emplacement in Canada. Nature Phys. Sci. $12,79-81$. 
Macintyre, R. M. 1973: Lower Tertiary geochronology of the North Atlantic continental margins. In Pidgeon, R. T. et al. (edit.) Geochronology-Isotope Geology of Scotland. ECOG 111, K1-K25.

Mitchell, J. G. 1972: Potassium-argon ages from the Cheviot Hills, Northern England. Geol. Mag. 109, 421-426.

Wager, L. R. \& Deer, W. A. 1938: A dyke swarm and crustal flexure in East Greenland. Geol. Mag. 75, $39-46$.

School of Physics,

The University,

Newcastle upon Tyne NE1 7RU,

U.K.

\title{
Computer supported geological photo-interpretation
}

\author{
Hans F. Jepsen and Keld S. Dueholm
}

\section{Introduction}

The research project supported by the Danish Natural and Technical Science Research Councils (SNF \& STF) and GGU aiming at evaluating the use of advanced photogrammetrical techniques in geological photo-interpretation (Dawes, 1977) has continued during the past year. Methods which combine geological photo-interpretation with photogrammetrical techniques have been described by Dueholm (1976) and Dueholm et al. (1977).

This report describes a procedure and an instrumentation which makes it possible to combine precise drawing of geological boundaries with computer supported interpretation. $300 \mathrm{~km}^{2}$ of south-eastern Washington Land, western North Greenland was selected as a test area. 10 vertical aerial photographs at a scale of about 1:50 000 cover the area.

During the summer 1976 one of the authors (HFJ, in Peel, 1977) spent two weeks in the test area and lithological sections were measured at several localities. The geology is characterised by sub-horizontal Cambro-Ordovician sandstones, dolomites and limestones disturbed by block faulting (fig. 50). The layering of the strata is very conspicuous on the aerial photographs and several marker horizons can be defined and measured in the stereomodels.

The Institute of Surveying and Photogrammetry, Technical University of Denmark (DTH) provided the photogrammetric instruments. A Planitop F-2 stereo plotter equipped with $x, y, z$ encoders connected via a digitising module to a desk calculator (HP 9815 A) was used. Coordinates are transferred from the instrument to the desk calculator either continuously or point by point by a foot pedal.

\section{Procedure}

On a geological boundary, which is assumed to be an even plane, at least three points are measured and stored in the desk calculator. The parameters of the plane are calculated and 